\title{
A SINISTRAL HELICOPSIS CF. INSTABILIS (ROSSMÄSSLER, 1838) FROM ROMANIAN LOESS
}

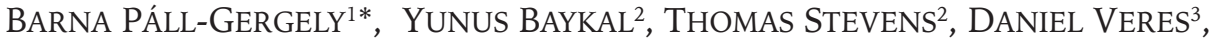 \\ ULRICH HAMBACH ${ }^{4}$
}

\begin{abstract}
${ }^{1}$ Plant Protection Institute, Centre for Agricultural Research, Herman Ottó Street 15, H-1022 Budapest, Hungary (e-mail: pall-gergely.barna@agrar.mta.hu); () https://orcid.org/0000-0002-6167-7221

${ }^{2}$ Department of Earth Sciences, Uppsala University, Villavägen 16, 75236 Uppsala, Sweden (e-mails: yunus.baykal@geo.uu.se, thomas.stevens@geo.uu.se); YB (1) https://orcid.org/0000-0002-9192-9944

${ }^{3}$ Romanian Academy, Institute of Speleology, Clinicilor 5, 400006 Cluj-Napoca, Romania (e-mail: dsveres@gmail.com); (1) https://orcid.org/0000-0003-3932-577X

${ }^{4}$ BayCEER \& Chair of Geomorphology, University of Bayreuth, 94450 Bayreuth, Germany (e-mail: ulrich.hambach@uni-bayreuth.de)

*corresponding author
\end{abstract}

\begin{abstract}
Here we report a single sinistral juvenile shell of Helicopsis cf. instabilis (Rossmässler), which was found in the Urluia loess section in south-eastern Romania. This $860 \mathrm{~cm}$ long profile comprises the last ca. $45 \mathrm{ka}$. Approximately six hundred conspecific dextral shells were found at various depths of the same profile.
\end{abstract}

KEY WORDS: chirality, reverse-coiled shell, Geomitridae

A reverse-coiled, juvenile shell found among normally coiled ones is surprising in itself for researchers and shell collectors. However, besides being only precious specimens, they provide important insights into the evolution of whole-body enantiomorphism.

Reverse-coiled lower-rank taxa are not equally frequent among all large groups of land snails. Namely, inverse genera and species are more frequent among reciprocally copulating than non-reciprocally copulating groups. The former are in most cases flat or globular shelled snails, whereas the latter are usually snails with high-spired shells. The reason for this difference in the ratio is that the mutant gene responsible for reverse coiling undergoes stronger selection (i.e. more rapidly eliminated) in reciprocally copulating populations (ASAMI et al. 1998). Thus, although we can assume that the mutation rate at the left-right polarity determinant locus is equivalent in all land snail groups, we encounter reverse-coiled shells more frequently in high-spired, than in flat or globular shelled species.

To provide further information for this topic, we report a single sinistral (Figs 1-2) shell of the genus Helicopsis Fitzinger, 1833 which was found during the examination of fossil shell samples from the Urluia loess section $\left(4^{\circ} 05^{\prime} 39.9^{\prime \prime} \mathrm{N}, 2^{\circ} 54^{\prime} 11.1^{\prime \prime} \mathrm{E}\right.$, $125 \mathrm{~m}$ a.s.l) in south-eastern Romania, where we sampled an $860 \mathrm{~cm}$ long profile continuously every 5 centimetres in the spring of 2019; it approximately comprises the last $45 \mathrm{ka}$. The study area is located on the Southern Dobrogea Plateau which is subjected to a semiarid climate driven by the strong influence of Eurasian continental anticyclones while the Atlantic climate influence is minimal (BANDOC \& PRĂVĂLIE 2015). The reported shell was found in the sampled profile at a depth of $420-425 \mathrm{~cm}$, embedded in pure loess deposited under glacial conditions (presumably early Marine Isotope Stage [MIS] 2, based on OBREHT 


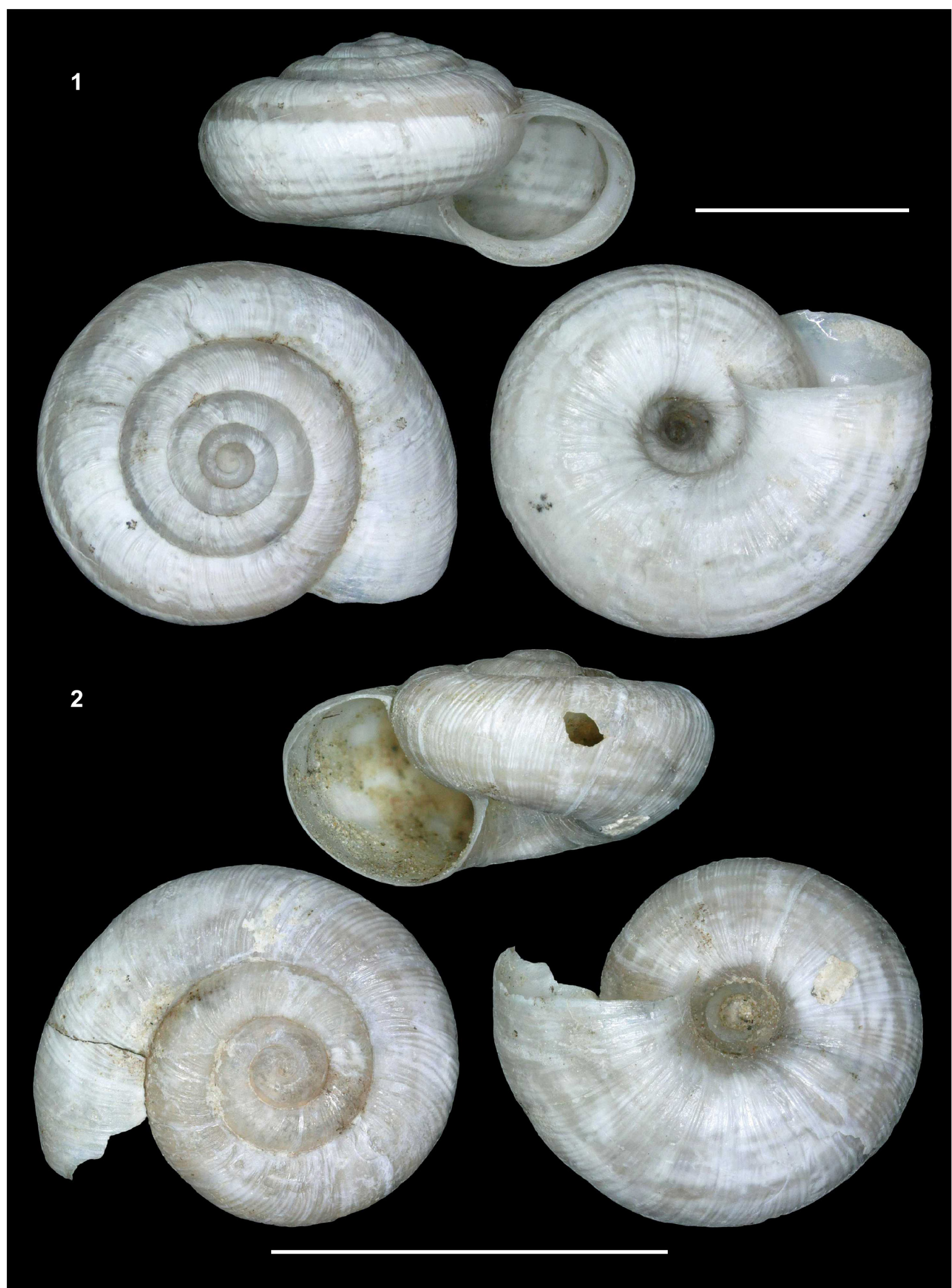

Figs 1-2. Shells of Helicopsis instabilis (Rossmässler, 1838) from a loess deposit in southeast Romania: 1 - adult, dextral shell from layer $535 \mathrm{~cm}-540 \mathrm{~cm}$; 2 - sinistral, juvenile shell from layer $420 \mathrm{~cm}-425 \mathrm{~cm}$. Scale bars $5 \mathrm{~mm}$ 
et al. 2017). Previous studies have suggested even more arid conditions for the study area during MIS 2 due to a strengthened Eurasian high pressure system compared to modern variability (OBREHT et al. 2017).

The Helicopsis species was present in nearly all samples from the topmost grass level $(0 \mathrm{~cm})$ until $705 \mathrm{~cm}$ depth. Between the depths of 710 to $860 \mathrm{~cm}$ Helicopsis was found in three samples only. Additional shell fragments from other samples between 710 to $860 \mathrm{~cm}$ could be identified as "Helicoidea sp.", although they probably also belong to Helicopsis. The $860 \mathrm{~cm}$ long loess profile we sampled covers approximately the last $45 \mathrm{ka}$, and among the 598 Helicopsis shells we found, only a single one was sinistral.

Although some species received attention in the last few years in phylogenetic papers (SYCHEV \&
SNEGIN 2016, DUDA et al. 2018), the taxonomy of the genus Helicopsis requires a revision, and identification of species is challenging. Among the species listed from Romania by GROSSU (1983) and WELTERSCHULTES (2012), we provisionally identify our species as Helicopsis instabilis (Rossmässler, 1838).

\section{ACKNOWLEDGEMENTS}

We are grateful to TAKAHIRO ASAMI (Shinshu University, Japan) for his information on the evolution of chirality. This study was supported by the MTA (Hungarian Academy of Sciences) Premium Post Doctorate Research Program for B. PÁLL-GERGELY and the Swedish Research Council to T. STEVENS (grant number 2017-03888).

\section{REFERENCES}

ASAMI T., COWIE R. H., OHBAYASHI K. 1998. Evolution of mirror images by sexually asymmetric mating behavior in hermaphroditic snails. American Naturalist 152: 225-236. https://doi.org/10.1086/286163

BANDOC G., PRĂVĂLIE R. 2015. Climatic water balance dynamics over the last five decades in Romania's most arid region, Dobrogea. Journal of Geographical Sciences 25: 1307-1327. https://doi.org/10.1007/s11442-0151236-1

DudA M., HARING E., Bieringer G., Eschner A., MRKVICKA A., MASON K. 2018. Taxonomic reassessment of Helicopsis austriaca Gittenberger, 1969 and its relationships to $H$. striata (O. F. Müller, 1774) and $H$. hungarica (Soos \& H. Wagner, 1935) (Eupulmonata: Helicoidea). Journal of Molluscan Studies 84: 432-450. https://doi.org/10.1093/mollus/eyy044

Grossu A. V. 1983. Gastropoda Romaniae. 4. Ordo Stylommatophora. Suprafam.: Arionacea, Zonitacea, Ariophantacea şi Helicacea. Editura Litera, București.

Obreht I., HAMBACH U., Veres D., ZEEDEN C., BÖSKEN J., Stevens T., Marković S. B., KLASEN N., Brill D., BUROW C., LEHMKUHL F. 2017. Shift of large-scale atmospheric systems over Europe during late MIS 3 and implications for Modern Human dispersal. Scientific Reports 7: 1-10. https://doi.org/10.1038/s41598-01706285-X

SYCHEV A. V., SNEGIN E. A. 2016. K problemye sistematiki roda Helicopsis (Gastropoda: Pulmonata: Hygromiidae) na territorii Vostochnoy Evropy. Ruthenica 26: 175-189.

WELTER-SCHUltes F. 2012. European non-marine molluscs, a guide for species identification. Planet Poster Editions, Göttingen.

Received: January 14th, 2020

Revised: February 6th, 2020

Accepted: February 7th, 2020

Published on-line: February 28th, 2020 